Covered in: Web of Science (WOS); EBSCO; ERIH+; Google Scholar; Index Copernicus; Ideas RePeC; Econpapers; Socionet; CEEOL; Ulrich ProQuest; Cabell, Journalseek; Scipio; Philpapers; SHERPA/RoMEO repositories; KVK; WorldCat; CrossRef; CrossCheck

2021, Volume 12, Issue 4, pages: 241-254 | https://doi.org/10.18662/po/12.4/372

\section{The Systematization and Preservation of Cultural Heritage of National Minorities in the Context of the Postmodern Philosophy}

\author{
Iryna SKAKALSKA ${ }^{1}$, \\ Oleksandra PANFILOVA², \\ Iryna SYDUN3, \\ Svitlana ORIEKHOVA, \\ Tetiana ZUZIAK ${ }^{5}$, \\ Iryna TATARKO 6
}

${ }^{1}$ Taras Shevchenko Regional Humanitarian Pedagogical Academy of Kremenets, Ukraine, Irunas@ukr.net

${ }^{2}$ Lesia Ukrainka Volyn National University, Lutsk, Ukraine, alka11@meta.ua

${ }^{3}$ Odessa I. I. Mechnikov National University, Odesa, Ukraine, syduniryna@,ukr.net

${ }^{4}$ Mariupol State University, Mariupol, Ukraine, sv.orehova@,ukr.net

${ }^{5}$ Vinnytsia Mykhailo Kotsiubynskyi State Pedagogical University, Vinnitsa, Ukraine, zuzyak@ukr.net

${ }^{6}$ Danube Institute of the National University

"Odessa Maritime Academy", Izmail, Ukraine, tatarkoirina01011979@,ukr.net
Abstract: The article studies the Jewish cemetery which provides a significant amount of historical information about various aspects of the life of the Jewish community which have long been out of focus. The objective of the research lies in proving the relevance of marginal culturally significant objects in the context of postmodern philosophy, as well as explaining and analyzing the compositional ways and peculiarities of plastic images of the facades of the gravestones in Kremenets, one of the Volyn areas of the Jewish culture in the 18th century - the early 19th century. The article focuses on the most common method of studying the monuments of Jewish gravestone epigraphy. The methodology of the research is based on the regionalist approaches to the problem and the application of culturological, retrospective comparativehistorical methods and the use of critical analysis. For the first time, the artistic and style peculiarities of the memorial plastic arts of Jewish cemetery in Kremenets are analysed and the historical factors that influenced them are explicated. It was proved that the historical and cultural value of the Jewish necropolis in Kremenets lies in its originality. The cemetery is one of the oldest in Europe and contains unique information on the history, customs and culture of the Jewish people. It can become a promising object of visit for postmodern consumers, interested in unpopular and marginal tourist artefacts.

Keywords: cultural heritage, marginality, synagogue, Jews, memorial plastic, symbols, Kremenets.

How to cite: Skakalska, I., Panfilova, O., Sydun, I., Oriekhova, S., Zuziak, T., \& Tatarko, I. (2021). The Systematization and Preservation of Cultural Heritage of National Minorities in the Context of the Postmodern Philosophy. Postmodern Openings, 12(4), 241-254. https://doi.org/10.18662/po/12.4/372 


\section{Introduction}

During hundreds of years, Kremenets (Ukraine) was a unique town where the traditions of the Ukrainian, Polish and Jewish people were closely interlaced. Each of them made a considerable contribution to the cultural traditions of the region. The town saved wonderful patterns of the Jewish carving art of the $18^{\text {th }}$ century and the early $20^{\text {th }}$ century. Nowadays, the main task of native art criticism is the preservation and careful attitude to historical relics of different times and peoples which are situated on the territory of Ukraine and are an integral part of the world cultural treasury. Considerable interest in Jewish art heritage in the $21^{\text {st }}$ century is connected with the fact that the peculiarities of culture, habits, traditions, funeral rituals of Jews, organization of cemeteries are still little known to those interested in artefacts unpopular from the point of view of traditional tourism.

Cultural achievements of the Jewish community in Kremenets are not cleared up in scientific sources and this confirms the actuality of the theme. Also, one lacks a general complex investigation of the problem of Jewish art on the territory of the region. Matsevas is an important source of historical and artistic investigations. During the study of Matsevas, one can get much historical information: the history of Jewish communities and the hierarchy in it, genealogy, biographies of individual representatives. One can also learn about the level of education of the Jewish population of the city (the number of rabbis and other clergy, connoisseurs of Torah). Also, the epitaph that was placed on Matseva in memory of the deceased is a source of folklore.

Among the Ukrainian scholars, a considerable contribution to the investigation of the Jewish cultural heritage of Podillia and Galicia was made by Boiko (2004), Khaimovich (2000), Kotliar (2001), Levkovich (2016). The Jewish architecture of Podillia is also analyzed in detail by the art critic Sokolova (2002). Old Jewish cemeteries in Ukraine have become the object of intensive investigation for the last decades. But the problem of formation of the original style of the Jewish carving in the Volyn towns was not the object of separate studying. Among modern publications devoted to the Jewish community in Kremenets, one can come across the article written by Yatsechko-Blazhenko (2014) in which the author observes the stages of settling the town territory by the Jews, the influence of their religious, economic and partly cultural activity on the formation and development of the town. Also, a significant part of contemporary publications is devoted to the Holocaust (Vurlovska, 2017). Tangent to the subject literature was used 
in the context of the work on this research, in particular the monograph of Pinchevska (2013) about Jewish artists.

However, the relevance of this article lies not so much in the lack of scientific studies on provincial Jewish burials as in the intuitive striving of postmodernism consumers for little-known marginal artefacts that embody cultic, thanatological, and apocalyptic aesthetics. Given the neglect of traditional vitalistic values, apocalyptic aesthetics becomes a source of personal reflection and generation of irrational meanings in the range of "being - non-being".

The purpose of the research is the investigation and analysis of compositional ways, the peculiarity of plastic representations on the tombstones of Kremenets, one of the Volyn centres of the Jewish culture in the $18^{\text {th }}$ century - the early $20^{\text {th }}$ century.

\section{A Postmodern Vision of Marginal Historical Heritage as a Potential Tourist Attraction}

New expressive tendencies of tourism were clearly manifested in a short period from the onset of the globalization era - to the heyday of postmodernism. First, it got rid of elitism and became massive and extremely segmented, ceased to require a personal culture of traveling people and special places that are visited. Organized and supported by the mass industry, which offers itself in the network and social media and quickly absorbed all fragmentary concepts: post Fordism, new age, ecotourism, sustainable tourism, etc. (Patiño et al., 2016). The trends of spontaneity, fluidity, authenticity and hyperreality have opened new opportunities for countries and locations that were not previously considered to be priority touristic facilities.

Post-modernistic consciousness refused standard tourist goals and typologies. The issues of sensory experience, existential authenticity, flexibility in choice have become of primary importance (Dujmovic \& Vitasović, 2015). These facts led to a new type of demand - offers in the field of tourist services, which leads to a new phenomenon - post-tourism.

In the context of globalization and postmodernism, the value of historical heritage, as an object of tourism, has become elitist and massive. Consequently, scholars and marketers have ignited interest in traditionally unattractive and ambiguous objects which gained popularity due to the Internet (Patiño et al., 2016). Therefore, the description and mass objectification of previously unexplored cult and sacred symbols of small tourist clusters are relevant now. 
This correlates with the views of Yanjun \& Jiaojiao (2017) who believe that tourism research has also undergone different trends. In the early stages, such research mainly focused on economic aspects of tourism and followed "the ideology of development, scale and speed" (Yanjun \& Jiaojiao, 2017). Modernism caused many fundamental social, environmental, and individual contradictions. At the same time, postmodernism has provided tourism research with "an opportunity for renewal" (Yanjun \& Jiaojiao, 2017). Also, Yanjun and Jiaojiao (2017) consider such antithetical pairs as "authenticity falsity", "harmony - power", "function - liberation" the greatest contradictions of mass tourism and postmodernism, while the category of power is crucial. Understanding such categories concerning tourism and cultural heritage suggests certain changes in the very concept of postmodernism. Thus, "power" in the broadest sense provides external, usually institutional, resources to support small tourism clusters (Yanjun \& Jiaojiao, 2017).

In the context of postmodernism, tourist, recreational and ecosystem services, even at the level of small towns, remain an important component of the comfort and well-being of urban residents. Therefore, they should be discussed from the standpoint of subjectivity. As noted by Abas et al. (2018), such objects "cannot be separated from spiritual and religious factors". In this regard, the symbolism associated with thanatological themes serves as a cognitive and receptive driver of permanent reflection of postmodern people between such extreme categories as "being - non-being", which helps one to generate personal meanings. To complete the picture of postmodern shifts in tourism, it is necessary to mention the so-called "Morbid Tourism". It attracts a traveller by agitating archetypal ideas about death, sinister forces and the otherworld (Blom, 2000). The objects of such tourism can include ancient burials, places of burial of stars of show business, places of bloody battles or frequent accidents. It is noteworthy that the tourism industry advertises such thanatologically labelled locations in every possible way as a sophisticated approach to death, which is an apical part of life.

Among the multimodal forms of tourism of the postmodern era it is worth allocate separately an altruistic or volunteer type. Mustonen (2006) indicates the similarity of such tourism with ancient, pilgrimage type. However, in the period of postmodernism, visiting the pilgrimage places may be completely deprived of spiritual meaning, and post-modernistic pilgrims behave as ordinary tourists, mechanically performing or not performing sacred actions. 
Postmodernism as a methodology that studies tourism, distinguishes in the latter phenomenon of deterritorialization (Xie, 2018). It is interesting because it explains and includes unstable models of morphological landscape, temporary territorial identity, primacy of entertainment over culture.

According to Thouki (2019), the cultural and spiritual repository of religion is an indispensable resource for forming social and cultural life in a post-secular era. The researcher state that, even though "pilgrims" and spiritually "enthusiastic" tourists have marked religious sites on nationwide cultural maps, religious sites have yet to achieve a holistic interpretive experience that will reveal deeper meanings of ecclesiastical art" (Thouki, 2019).

Upadhyay (2019) claims that postmodern tourism has always been related to mystification, plurality, prospects, problems, and risks. If one focuses on confusions, risks, and uncertainties of both real and imaginary associated with behavioural changes, bizarre tourism, and political instability, one should reconsider culture, traditions, legitimacy and cultivate an innovative socio-cultural, political, and technological understanding of issues in postmodern tourism (Upadhyay (2019).

Given postmodern philosophy, cultural heritage is evaluated rather ambivalently. On the one hand, it focuses on consumer tendencies of late capitalism (the consumption of the popular) and, on the other, on what is real. In this regard, Hannabuss (1999) indicates that "experience is increasingly a commodity provided by tourism and the heritage industry". Thus, heritage allows postmodernism to offer some relevant perspectives (Hannabuss, 1999).

Considering aesthetic and consumer values of postmodernism, the elements of Shinto and Abrahamic religious traditions in today's nd historical artefacts remain relevant and provide them with "internal cognitive logic" (Afanasov, 2020; Nerubasska et al., 2020; Nerubasska \& Maksymchuk, 2020). Postmodern and post-secular types of analysis, as well as elements of postmodern philosophy, that are applied to even incoherent religious and thanatological symbols, can reveal hidden plot and explicit (valid for marketing and tourism) references to religious, apocalyptic and thanatological motives (Afanasov, 2020).

\section{Jewish Matzevot as an Object of Kremenets Artistic and Historical Heritage}

The Jews in Volyn created their rich history and culture during the centuries. Kremenets was one of the biggest centres of the Jewish culture 
and education of Volyn, some of the Jewish famous personalities were born and lived there. The appearance of the first representatives of the Jewish culture in Kremenets is dated back to 1438 , e.g., to the $15^{\text {th }}$ century. According to the statistics for 1889 Kremenets county was inhabited by 9260 men and 7024 women of the Jewish population, while in Kremenets there were 2295 men and 2423 women (Matskevich, 1889). At the beginning of the $20^{\text {th }}$ century, according to the census, the Jewish community counted 6397 individuals. It made more than 40 per cent of the inhabitants (Kotliar, 2001). The numerousness of the community begins to grow in the years of the World War I. Valuable evidence of the existence of the ancient Jewish community in the $15^{\text {th }}$ - the $16^{\text {th }}$ centuries is the cemetery, the so-called "okopysko". The first buryings here are dated back to the $16^{\text {th }}$ century. The cemetery is situated on one of the slopes of the Kremenets mountains and occupies the area of about 2 hectares. Nowadays, the state of the tombstones is unsatisfactory. The Jewish cemetery in Kremenets is one of the oldest and biggest ones in Europe which still survived. "Beit almain" or "a house of eternity" - this is how the Jews name a cemetery in which, according to the Jewish tradition, they bury the members of their community. The ground in a cemetery is considered to be sacred (Kotliar, 2001). Comparatively distant location of the synagogue and necropolis in Kremenets is typical not only for Volyn but also for some towns of Galicia. Despite full destruction of authentic wooden architecture of the Jewish city block and the fact that Jewish tombstones were used for paving roads in the years of the World War II, the Kremenets Jewish cemetery, situated in Dzherelna street, contains a lot of interesting information. Its gravestones carry some facts about culture, traditions and separate personalities of the certain ethnic group. The cemeteries in the towns and villages of Volyn and Galicia had peculiarities of their own. They played an important role in the identification of a national contingent of the town, determined the limits of the Jewish district. Not every Jewish community had the right to keep its cemetery. The Jewish cemeteries had their interior order and established rules of supervision: they were divided into sections. The investigated and documented Jewish cemetery takes a large amount of historical information about the various aspects of the life of the Jewish community. Historical data drawn from Matsevas can be obtained by reading the information on the tombstone or deciphering symbols. As a rule, side to side were buried a husband and a wife, a brother and a sister, prominent rabbis, public and cultural figures (Boiko, 2004). There were cases when the cemeteries of rabbis were situated near synagogues on the territory of the town centre (Boiko, 2004). 
Buryings in the Kremenets necropolis are situated according to historical periods: the higher, the newer tombs. At the foot of the mountain, the matsevas are dated back to the $16^{\text {th }}$ century, the upper part is occupied by the tombstones of the $19^{\text {th }}$ and the first half of the $20^{\text {th }}$ centuries. It is known that Jewish coats of arms did not exist till the $18^{\text {th }}$ century but Jewish symbolism, developed on tombstones, became the book which told about a dead man and his family (Boiko, 2004, p. 244). Traditionally decorated symbolic composition of a carved ornament situated in an upper part, determines its artistic value. On the territory of Ukraine, the most perfect matsevas of the $18^{\text {th }}-19^{\text {th }}$ centuries were founded in Podillia, Galicia and Volyn. Here magnificent ornamental art related with arts-and-crafts of the people, among whom the Jews lived, flourished best of all. At the beginning of the $18^{\text {th }}$ century an original style of carving with numerous local variants was formed (Kuznetsov, Sataniv, n.a.).

\section{Representations on Matzevot as Reflection of Religious and Social Status}

Representations illustrate and complete the texts of epitaphs through picturesque symbols. Signs-symbols, represented on the matsevas, reflect the religious and social status of the dead, his profession, personal qualities and so on. Here one can find symbolic pictures of death and immortality as well as personal ancestral signs. The epitaphs, written in Ivrit (Hebrew), are distinguished by their variety and a good deal of quotations from the Bible. They belong to the most interesting and weighty sources of investigation. The only stable elements here were: a name of the dead, his or her father's name and date of death. All the rest information could be specifically encoded in a carved decoration of the tombstone (Boiko, 2004). An epitaph telling about the individuality of the dead, his or her good deeds is also a good source of genealogical information and has a clear-cut structure. As a rule, it consists of 4 elements: an introductory formula, a name of the dead, date of death according to the Jewish calendar and a blessing. Some epitaphs include the quotations from the Bible or Talmud like formulas of eulogy of the dead. Matsevas were mostly orientated to the East. Very often, except the text of an epitaph (as a rule situated below the composition), were used the letters which were arranged either together (in one geometry element) and appeared in a role of the title of the composition, or separately and grouped into different geometry elements: a circle, a square, a rectangle, a rhomb, a semicircle, a segment and so on. Most tombstones in Kremenets were made of local stones and were usually erected in a year after death. Except for vertical gravestones horizontal stones were also put up (Boiko, 
2004). They were often covered with a layer of soil. Such loglike sings which can be quite seldom found in the Jew cemeteries that remain uninjured are situated in Kremenets. The whole slope of the mountain is studded with the tombstones which lie on the ground like small coffins. The tombstones decorated with ornaments, symbols and texts have a various configuration. The Kremenets necropolis counts about fifteen forms among which rectangular and arched vertical tombstones are the most commonly used. Vegetable and architectural ornaments are the main kinds of decoration of the tombstones.

It is well known that decorative tombstones of the $18^{\text {th }}-19^{\text {th }}$ centuries are the most outstanding examples of folk art of the Eastern European Jews. Carving on the stone is closely connected with other kinds of folk art: carved wooden decoration, painted ceilings and metal candelabras of synagogues, ritual objects, utensils etc (Kotliar, 2001). The first decorated matsevas appeared in large cultural centres of Eastern Europe (Prague, Krakow) at the end of the $16^{\text {th }}$ century and developed under the influence of the art of Renaissance (Kotliar, 2001).

On the monuments of the beginning of the $17^{\text {th }}$ century, we can see new figurative images: lions, gryphons, wreaths or crowns. The further development of carving on a stone is represented by numerous examples from Podillia, Galicia, Volyn (Medzhybozh, Satanov (Podillia), Vyshnivets (Volyn)). Original, self-sufficient style of carving on a stone with numerous local variants, unity of composition and vivid language is formed in Podillia and Volyn at the beginning of the $18^{\text {th }}$ century. Degeneration and vanishing of this kind of fine arts take place in the middle and the second half of the XIX $^{\text {th }}$ century (Kotliar, 2001).

Reliefs of the tombstones have a rich complex of descriptive symbolism. Images of a human being are not found here as they are banned by the second commandment ("Do not put someone on a pedestal") (Kotliar, 2001). The carvers of the $17^{\text {th }}-18^{\text {th }}$ centuries very often worked in the baroque style. Here one may find the elements of "pan-European" style combined with the elements of "Kossack baroque" - the ornaments typical for the Ukrainian arts-and-crafts (Kuznetsov, n.a.). Among the numerous pictures of the Kremenets matsevas a vegetable ornament which comes from the Tree of life, as investigators consider, is the most commonly seen. Sometimes the pictures are laconic and are situated in the upper part of a tombstone over the text of an epitaph, sometimes they fill in arched consummations of portals and borders. The pictures of trees, especially the oak tree, vine, fruit can be often found. A vine is considered to symbolize in the Jewish tradition Shekhina - God's presence (Kuznetsov, n.a.). Grapes 
are also a symbol of fertility and may also signify God's court (Levkovich, 2016). Mirror symmetry of most such pictures is their characteristic feature.

On the gravestones, we can also find 4 variants of ritual candlestick Menora which is typical for female buryings. A candlestick is a symbol of female devotion. Among the buryings of the $18^{\text {th }}-$ the beginning of the $19^{\text {th }}$ centuries one can come across three massive tombstones with the picture of a crown put in a frame of vegetable ornaments. The tombstones are situated side by side and most likely belong to the members of the same honourable family. The image of a crown over some symbol emphasized its high importance, it is a symbol of a good name. A part of one more symbol of female buryings - a bird - is found only in one case on a half-ruined matseva. It may denote the name Feigl-Tsippora (a bird) but generally, doves, swallows, storks, pelicans are the symbols of a careful mother, while eagles in Jewish mythology symbolize God.

At the same time, a dove was sometimes represented on the tombstones of the people with the name Iona (a dove). Ornamental epitaph compositions combined with the pictures of animals is a widespread Jewish tradition. Animal themes can be also found among the matsevas of the Kremenets necropolis. Here one can see stylized figures of a lion, a bear, a hare, a unicorn. They were often represented in medallions and supplemented with flower festoons and arabesques. For example, a lion on the gravestone of Arie Leiba is a heraldic sign of the tsar David home, a bear was pictured on the tombstones of Dov-Ber. Among the interesting symbols of the Kremenets buryings is a bear with grapes. It is a symbol of the Bible explorers who come back to the Jewish people in a desert with the good news about the fertility of the Khanaan Land (Levkovich, 2016; Panair, n.a.). Sometimes a bunch of grapes in the bear's clutches denotes left numerous heirs of the dead. And only one half-ruined tombstone in Kremenets has the picture of a unicorn. This animal symbolizes goodness, the strength of mind, probity. Unicorns near the Tree of Life are the symbols of defence and protection.

The picture of fighting of a unicorn with a lion symbolizes the contradiction of the dead's character. To the widespread symbols of the Kremenets cemetery, we also refer pictures of a jug. Sometimes it stands side by side with a bowl or a plate, sometimes on a tray. It is known that a dipper, a cup or a jug are the symbols of the clan of the Levits. The other symbols of Jewish matsevas have more complicated semantics. It is necessary to mention that all these descriptive motives are subordinated to the idea of temporary staying in a grave, future rising from the dead, 
emphasizing the virtues of the dead. In this sense, a picture adds to the text (Kotliar, 2001; 2011).

\section{Conclusions}

Postmodern people are more and more willing to visit unpopular, marginal, and ambiguous objects in terms of traditional aesthetics. This is due to the growing value of exotic tourist destinations, interest in individual creative modalities, as well as narrow ethnic artefacts as manifestations of the subjective (Trifonas, 2003). This leads to significant segmentation of tourism and, at the same time, poses serious challenges to tourism clusters. Thus, there appears to be the need for cultural and aesthetic assessment of atypical objects, namely, abandoned settlements, burials, dilapidated but culturally significant buildings, and other residual "post-cultural" objects.

In this regard, the historical and cultural value of Jewish cemeteries is their identity, high artistic level of tombstones and their information content. So, one can sum up that symmetrical composition, repetition of traditional motives with original author's expression given to them by their craftsmen, dominate in epitaph carving of the Kremenets tombstones. A lot of ideas connected with the meaningfulness of death in the Jewish cultural tradition found their expression in the epitaphs of the Kremenets matsevas. In addition to the motives inherent to the Eastern peoples, one can notice here a good few patterns which were used in the architecture and the Ukrainian arts-and-crafts in the baroque period. It is determined, that in the process of a long artistic practice national peculiarities of decorative carving were formed which corresponded to esthetic requirements of the Jews and ensured the following to the rituals of their religion.

For many centuries the Ukrainian and Jewish people had been living side by side mutually enriching one another. Nowadays, it is very important to take care and maintain the cultural achievements of all the national minorities that formerly lived or are still living in our land. It is also well worth starting the systematization of the cultural achievements of different national minorities on the territory of the region. The results, received in the process of the investigation of the history and artistic monuments of the national minorities in Kremenets, will contribute to the preservation of the cultural heritage of Volyn and the popularization of non-traditional tourism facilities 


\section{Acknowledgement}

The authors of the publication express the sincere gratitude to Professor Afanasii Lomakovych - rector Taras Shevchenko Kremenets Regional Academy. It should also be noted that in this article, the authors performed a partial, but necessary work: Oleksandra Panfilova acted as a consultant on Jewish cultural heritage, Iryna Sydun systematized the photo and video of the tombstone epigraphy and sorted it according to certain methodological and art parameters. Tetiana Zuziak has reviewed the trends of postmodernistic tourism, which proved the relevance of our article. By applying retrospective, culturological, comparative-historical and critical types of analysis, Iryna Skakalska in cooperation with Svitlana Oriekhova analyzed composite techniques, specifics and content of plastic images of artifacts, etc. Iryna Tatarko managed to combine the above-mentioned observations and work results in a holistic text.

\section{References}

Abas, A., Aiyub, K., Abdullah, N. A., \& Anuar, N. N. M. (2018). The cultural ecosystem services: from philosophical post-modernism perspectives. Journal of Food, Agriculture \& Environment, 16(3-4), 45-

50. https://www.researchgate.net/publication/329235278 The cultural_e cosystem services From philosophical post-modernism_perspectives

Afanasov, N. (2020). The depressed Messiah: Religion, science fiction, and postmodernism in neon genesis Evangelion. State, Religion and Church, 7(1), 47-66. https://cyberleninka.ru/article/n/the-depressed-messiah-religionscience-fiction-and-postmodernism-in-neon-genesis-euangelion/viewer

Blom, T. (2000). Morbid tourism - a postmodern market niche with an example from Althorp. Norsk Geografisk Tidsskrift $\square$ Norwegian Journal of Geography, 54(1), 29-36. https://doi.org/10.1080/002919500423564

Boiko, K. S. (2004). Yevreiski tsvyntari v arkhitekturnomu landshafti Skhidnoi Halychyny: problemy zberezhennia i stan doslidzhenosti Jewish cemeteries in the architectural landscape of Eastern Galicia: the problems of preservation and level of investigation]. Visnyk Lvivskoyi politekbniky, 505, 243-250. http://ju.org.ua/ru/publicism/902.html

Dujmovic, M., \& Vitasović, A. (2015). Postmodern society and tourism. Proceedings of the 3rd International Scientific Conference on Tourism in Southern and Eastern Europe, 3, 49-62. https://ssrn.com/abstract $=2637255$

Hannabuss, S. (1999). Postmodernism and the heritage experience. Library Management, 20(5), 295-303. 
The Systematization and Preservation of Cultural Heritage of National ... Iryna SKAKALSKA, et al.

https://www.emerald.com/insight/content/doi/10.1108/0143512991027 $\underline{6280 / \text { full } / \mathrm{html}}$

Khaimovich, B. (2000). The Jewish Bestiary of the $18^{\text {th }}$ century in the Dome Mural of the Khodorov Synagogue. Jews and Slavs, 7, 130-

187. https://www.academia.edu/10649853/The Jewish Bestiary of the 18th Century in the Dome Mural of the Khodorow Synagogue

Kotliar, I. O. (2001). Synahoby Ukrainy druboi polovyny XVI $\square$ pochatku XX stolit yak. istoryko-kulturnyi fenomen [Synagogues in Ukraine in the second part of the $16^{\text {th }}$ century - the beginning of the $20^{\text {th }}$ century as a historical and cultural phenomenon]. [Abstract of $\mathrm{PhD}$ thesis, Kharkiv State Academy of Culture, Kharkiv]. Disslib. http://www.disslib.org/synahohy-ukrayiny-druhoyipolovyny-xvi-pochatku-xx-stolit-jak-istoryko-kulturnyi.html

Kotliar, O. R. (2011). Obrazy shtetla v ukrainskomu mystetstvoznavstvi pershoi tretyny XX st. u konteksti yevropeiskykh khudozhnikh poshukiv [Images of the shtetl in the Ukrainian art criticism of the first part of the $20^{\text {th }}$ centuries in the context of the European art search]. [Abstract of $\mathrm{PhD}$ thesis, Kharkiv State Academy of Design and Arts, Kharkiv]. Disslib.

http://www.disslib.org/obrazy-shtetla-v-ukravinskomu-mystetstvipershoyi-tretyny-khkh-st-u-konteksti.html

Kuznetsov, Y. (n.a.). Sataniv. Yevreiske kladoryshche 16-19 st. [Sataniv. Jewish cemetery of the $16^{\text {th }}$ century $-19^{\text {th }}$ century]. Retrieved from http://ukrainaincognita.com/ru/comment/reply/1006.

Levkovich, N. Y. (2016). Dekoratyvno-u乏hytkove mystetstvo yeureiv Skbidnoi Halychyny XVIII - pershoi tretyny XX st.: typolobiia, symvolika, khudozhni osoblyvosti Jewish art-and-crafts of Eastern Galicia of the $18^{\text {th }}$ century - the first part of the $20^{\text {th }}$ century: typology, symbolism, artistic peculiarities] [Abstract of postdoctoral thesis, Lviv National Academy of Arts, Lviv]. University of Kiev Library. http://www.library.univ.kiev.ua/ukr/elcat/new/detail.php3?doc id $=1700$ $\underline{976}$

Matskevich, Y. (1889). Pamiatnaia knižbka Volynskoi gubernii na 1890 god [The memorial book of Volyn province for 1890]. Tipografiia Gubernskogo Pravleniia.

Mustonen, P. (2006). Volunteer tourism: Postmodern pilgrimage? Journal of Tourism and Cultural Change, 3(3), 160-177. https://doi.org/10.1080/14766820608668493

Nerubasska, A., \& Maksymchuk, B. (2020). The Demarkation of Creativity, Talent and Genius in Humans: a Systemic Aspect. Postmodern Openings, 11(2), 240255. https://doi.org/10.18662/po/11.2/172

Nerubasska, A., Palshkov, K., \& Maksymchuk, B. (2020). A Systemic Philosophical Analysis of the Contemporary Society and the Human: New 
Potential. Postmodern Openings, 11(4), 275-292.

https://doi.org/10.18662/po/11.4/235

Panair, D. (n.a.). Levy, yedynoroby ta vedmedi (shcho oznachaiut davni bareliefy?) [Lion, unicorns, and bears (what do the ancient bas-relieves mean?)]. Retrieved from http://gorodok-region.narod.ru/symvoly j.html

Patiño, M. G., Medina, F. X., \& Arilla, J. M. P. (2016). New trends in tourism? From globalization to postmodernism. International Journal of Scientific Management and Tourism, 2(3), 417-433. http://www.ijosmt.com/index.php/ijosmt/article/view/147

Pinchevska, B. M. (2013). Tvorchist yevreiskykh khudozhnykiv Skhidnoi Halychyny 19001939 rokiv [The creativity of Jewish artists from Eastern Galicia 19001939]. Vsesvit. http://uartlib.org/allbooks/istoriya-ukrayinskogomistetstva/b-m-pinchevska-tvorchist-yevrejskyh-hudozhnykiv-shidnoyigalychyny-1900-1939-rokiv/

Sokolova, A. V. (2002). Traditsionnaia arkhitekturnaia sreda shtetlov Podolii: XVIIInachalo XX vv [Traditional architectural surroundings of shtetls of Podolia: the XVIII $\underline{\underline{t}}$ - the beginning of the XX $\underline{\text { th }}$ centuries] [Abstract of $\mathrm{PhD}$ thesis, Russian Academy of Architecture and Construction Sciences, Saint Petersburg]. Dissercat. https://www.dissercat.com/content/traditsionnaya-arkhitekturnaya-sredashtetlov-podolii-xviii-nachalo-xx-vv

Thouki, A. (2019). The role of ontology in religious tourism education $\square$ exploring the application of the postmodern cultural paradigm in European religious sites. Religions, 10(12), 1-19. https://eprints.whiterose.ac.uk/154066/

Trifonas, P. (2003). The ethics of science and / as research: deconstruction and the orientations of a new academic responsibility. Educational Philosophy and Theory, 35(3), 285-295. https://eric.ed.gov/?id=EJ983459

Upadhyay, P. (2019). Tourism in Nepal, real or hyperreal: a postmodern perspective. NUTA Journal, 6(1-2), 39-46. https://doi.org/10.3126/nutaj.v6i1-2.23227

Vurlovska, M. (2017). Natsystskyi teror proty yevreiv drohobycha (istoriia rodyny drimeriv) [Nazi terror against the Jews of Drohobych (a story of the Dreamer family)]. Skbidnoievropeiskyi istorychnyi visnyk, 5, 177-183. http://nbuv.gov.ua/UJRN/eehb_2017_5 23

Xie, P. F. (2018). Chapter 4: Postmodernism: progressing research in tourism. In R. Nunkoo (Ed.), Handbook of research methods for tourism and hospitality management (pp. 43-52). Edward Elgar Publishing Limited. https://doi.org/10.4337/9781785366284.00009

Yanjun, X., \& Jiaojiao, S. (2017). Reflection and re-reflection in tourism study: a review on the modernism and postmodernism paradigm in Aramberri's 
The Systematization and Preservation of Cultural Heritage of National ... Iryna SKAKALSKA, et al.

framework of criticism. Tourism Tribune, 32(2), 13-

21. https://en.cnki.com.cn/Article en/CJFDTotal-LYXK201702008.htm

Yatsechko-Blazhenko, T. V. (2014). Nerukhomi pamiatky yevreiskoi kulturnoi spadshchyny mista Krementsia [Immovable monuments of Jewish cultural heritage of Kremenets city]. Hileia: nankovyi visnyk, 90, 144-147.

https://chtyvo.org.ua/authors/Yatsechko-

Blazhenko_Tetiana/Nerukhomi_pamiatky_ievreiskoi_kulturnoi_spadschyn y mista Krementsia/ 